\title{
SCHOOL STRATEGIES IN STRENGTHENING STUDENT RESILIENCE IN DISASTER-PRONE AREAS
}

\author{
Siti Irene Astuti Dwiningrum ${ }^{1 *}$, Khirjan Nahdi ${ }^{2}$, Aswasulasikin ${ }^{2}$, \\ Dyah Respati Suryo Sumunar ${ }^{1}$, Rukiyati ${ }^{1}$, Ebny Sholikhah ${ }^{1}$ \\ ${ }^{1}$ Universitas Negeri Yogyakarta, Indonesia \\ ${ }^{2}$ Universitas Hamzanwadi Lombok, Indonesia \\ *e-mail: siti_ireneastuti@uny.ac.id
}

\begin{abstract}
Resilience is needed by students who live in disaster-prone areas. With strong resilience, students can implement disaster mitigation. This study aims to describe the profile of students' resilience and the strategies carried out by students in strengthening personal resilience. The mixed method research approach was conducted on a research population of SMA/SMK in Lombok Regency, specifically North Lombok, East Lombok, and West Lombok. The respondents were 779 people from 10 schools in disasterprone areas determined by the Slovin formula. Student resilience profiles were explored according to Reivich and Shatte. Data on how teachers increase students' resilience were obtained from a focus group discussion (FGD) with 20 teachers from 10 schools. The results of the research prove that the personal resilience profile of students in Lombok from the seven aspects is still not optimal, which is not enough to form resilience personalities (less than 60\%). This study affirms that personal resilience is essential in building school resilience to provide a massive contribution to education and disaster mitigation. Regarding recommendations for schools to increase student resilience, it can be done by increasing resilience resources, strengthening social support, having resilient teachers, building resilient schools all aspects of which must work systemically and synergistically.
\end{abstract}

\section{Keywords: resilience, disaster mitigation, personal and emotional regulations, self efficacy}

\section{STRATEGI SEKOLAH DALAM MEMPERKUAT RESILIENSI SISWA DI DAERAH RAWAN BENCANA}

\begin{abstract}
Abstrak: Resiliensi dibutuhkan oleh siswa yang tinggal di daerah rawan bencana. Dengan resiliensi yang kuat, siswa dapat melakukan mitigasi bencana. Penelitian ini bertujuan untuk mendeskripsikan profil resiliensi personal siswa dan strategi yang dilakukan oleh sekolah untuk memperkuat resiliensi siswa. Pendekatan penelitian "mixed-method" dilakukan pada siswa SMA/SMK di Kabupaten Lombok, khususnya Lombok Utara, Lombok Timur, dan Lombok Barat. Responden adalah 779 orang dari 10 sekolah di daerah rawan bencana yang ditentukan dengan rumus Slovin. Untuk memahami profil resiliensi personal siswa digunakan konsep Reivich dan Shatte. Untuk memahami bagaimana guru meningkatkan resiliensi siswa diperoleh dari data focus group discussion (FGD) yang diikuti oleh 20 guru dari 10 sekolah. Hasil penelitian menunjukkan bahwa profil resiliensi siswa di Lombok yang terbentuk dari tujuh aspek masih belum cukup optimal membentuk resiliensi siswa $(<60 \%)$. Studi ini membuktikan bahwa resiliensi personal dibutuhkan dalam membangun resiliensi sekolah yang berkontribusi untuk pendidikan dan mitigasi bencana. Rekomendasi untuk sekolah bahwa untuk meningkatkan resiliensi siswa dapat dilakukan dengan meningkatkan sumber resiliensi, menguatkan dukungan sosial, memiliki guru yang resilien, membangun sekolah yang resilien, yang kesemua aspek harus bekerja secara sistemik dan sinergis.
\end{abstract}

Kata Kunci: ketahanan, mitigasi bencana, regulasi pribadi dan emosional, keberhasilan diri

\section{INTRODUCTION}

Disaster education, which includes education on disaster risk, mitigation, and preparedness strategies, is one approach to reduce the negative consequences of disasters (Suhardjo, 2011). According to Hyogo Framework forAction 2005-2015, and the recently adopted Sendai Framework for Disaster Risk Reduction 2015- 
2030 addresses knowledge-related issues and provides the opportunity to highlight the critical role of knowledge in disaster risk reduction (Weichselgartner \& Pigeon, 2015). The goal of disaster education is 'to build a culture of safety and resilience at all levels,' to reduce the adverse social and economic impacts of harm. Disaster education programs and media have historically targeted adults with information about disaster risks and ways to prepare their families, such as creating family emergency plans, buying houses and renters insurance, and stocking up on food, water, and supplies. Disaster education is not easy, because it must be well prepared by all elements of the community so that it could build community preparedness and awareness (Tohani \& Wibowo, 2019).

Schools have a very important role in mitigation education. With disaster education, mitigation goals can be optimized, and to be more responsive and proactive in dealing with disasters. School as a critical environment is expected to develop teachers' and students' resilience optimally, and to evoke them from adversity and adapt to various changes. Teachers have a direct role in developing students' resilience (Dwiningrum, Prihastuti, \& Suwarjo, 2013). The involvement of teachers in improving school resilience is determined by many aspects such as personal competence, social competence, school culture, and school facilities. Schools have an important role in building and developing students' personal resilience because resilient students will play a role in disaster mitigation. Many strategies can be done by schools to provide material that supports students' readiness in facing disasters (Metzl \& Morrell, 2014).

Strengthening resilience is important for improving the quality of life of the people. This is in agreement with the results of research that in building resilience when analyzed by cross-sectional there is a relationship between quality of life-related to health, well-being, and disaster preparedness (Gowan, Kirk, \& Sloan, 2014). Therefore, strengthening resilience will be built the ability to survive and adapt in the face of disaster. Interdisciplinary and integrated approaches are considered more effective in managing disasters (Twigg \& Bhatt, 1998).
Teacher has an important role in forming resilient students who have the following attributes: stable relationships with peers; developing problem-solving skills; design a realistic future; positive and effective attitude in doing the task; experiencing success in various fields of life; communicate effectively; strong attachment to at least one adult; and the attitude of responsibility for themselves and others (Shiwaku, Sakurai \& Shaw, 2016). For teachers, resilience is important to increase the ability and adaptability of various changes and demands of their social role (Barankin \& Khanlou, 2009).

Research related to resilience issues has not been done much in schools. One area that has not been studied much is Lombok, even though in 2018 there were earthquakes several times in succession. This condition requires the role of schools for disaster mitigation because the impact of the disaster occurs in the school environment. Disaster events require integrated mitigation preparedness, because the impacts are very detrimental to the community, as is the impact of the earthquake in Lombok, Indonesia. Table 1 presented the data on losses caused by the earthquake in Lombok.

It can be concluded that the material and non-material disaster damage is relatively large, and the funds needed for rehabilitation are also relatively large. This proves that disaster management requires strong mitigation, both related to the material and non-material aspects. In this context, disaster mitigation that is structural and non-structural must be builtin synergy so that the results are more optimal in reducing the impact of disasters. Therefore, this paper will explain the importance of understanding student resilience profiles and strategies to develop student personal resilience in disaster-prone schools, particularly in postearthquake in Indonesia Lombok. Research on student resilience profiles will contribute to the development of personal reliability that must be carried out by teachers and schools so that students in disaster-prone areas are more resilient and have a role in disaster mitigation. The results of this study are a source of reference for the development of community-based resilience to be applied in schools. 
Table 1. Data on the Lombok Earthquake Losses 2018

\begin{tabular}{|c|c|}
\hline Aspect & Data on Losses \\
\hline $\begin{array}{l}\text { Number of } \\
\text { victims }\end{array}$ & $\begin{array}{l}\text { The total death toll was } 564 \text { people, } 82.8 \text { percent of all deaths or around } 467 \text { people were in } \\
\text { North Lombok. Injury reached } 1,584 \text { people where } 829 \text { people or } 52.3 \text { percent came from } \\
\text { North Lombok. }\end{array}$ \\
\hline $\begin{array}{l}\text { The number } \\
\text { of damaged } \\
\text { houses }\end{array}$ & $\begin{array}{l}\text { The number of damaged houses reached } 167 \text { units and } 33.3 \text { percent or } 55,924 \text { units were in } \\
\text { West Lombok. That is why; North Lombok is the largest refugee location. Of the total } 445,343 \\
\text { people displaced in NTB, the majority came from West Lombok as many as } 105,453 \text { people. }\end{array}$ \\
\hline Infrastructure & $\begin{array}{l}\text { There were } 214 \text { infrastructures such as bridges, roads, bus terminals, and docks, irrigation to } \\
\text { dams that were damaged and affected by the disaster. The most damage was experienced by } \\
\text { irrigation networks by } 45 \text { percent or } 97 \text { units, then for } 28 \text { percent or } 61 \text { units, SPAM (Drinking } \\
\text { Water Supply System) and WWTP (Wastewater Treatment Installation) by } 15 \text { percent or } 32 \\
\text { units. In accumulation, the most damage to infrastructure occurred in North Lombok with } 85 \\
\text { units. }\end{array}$ \\
\hline $\begin{array}{l}\text { Education } \\
\text { facilities }\end{array}$ & $\begin{array}{l}\text { For schools, the number of damaged and affected reached } 1,194 \text { units of which } 53 \text { percent or } \\
\text { around } 639 \text { units were elementary school buildings. Then PAUD } 254 \text { units, SMP } 155 \text { units, } \\
\text { SMA } 72 \text { units, SMK } 56 \text { units, and SLB } 8 \text { units. The highest total damage to education facilities } \\
\text { occurred in North Lombok with } 294 \text { school units. }\end{array}$ \\
\hline $\begin{array}{l}\text { Health } \\
\text { facilities }\end{array}$ & $\begin{array}{l}\text { This earthquake caused } 321 \text { health facilities to be damaged with } 26.48 \text { percent of them located } \\
\text { in West Lombok. While } 35.85 \text { percent or as many as } 115 \text { units experienced by the Village } \\
\text { Health Post or Poskedes. Then there werealso } 86 \text { health centres and } 9 \text { hospitals. }\end{array}$ \\
\hline $\begin{array}{l}\text { House of } \\
\text { worship }\end{array}$ & $\begin{array}{l}\text { There were } 630 \text { damaged mosque units, } 461 \text { prayer rooms, } 1 \text { church in Mataram, } 1 \text { temple in } \\
\text { North Lombok, and } 50 \text { temples. Most mosque damage was in East Lombok with } 267 \text { units and } \\
\text { most pure was in West Lombok. }\end{array}$ \\
\hline $\begin{array}{l}\text { Economic } \\
\text { facilities }\end{array}$ & $\begin{array}{l}\text { Damaged traditional markets, both heavy and light, reached } 46 \text { units and most were in North } \\
\text { Lombok with } 25 \text { units. Then } 566 \text { kiosks and shops and most in West Lombok with } 294 \text { units. } \\
\text { Then in total, there were } 138 \text { damaged hotels, } 105 \text { in North Lombok and } 33 \text { in West Lombok. }\end{array}$ \\
\hline
\end{tabular}

\section{METHOD \\ Population}

This study aims to describe the resilience of high school/vocational students in Lombok, Indonesia. The study was conducted on high school/vocational students in Lombok regency, especially North Lombok, East Lombok, and West Lombok.

\section{Sample}

Research respondents were determined by purposive sampling technique. The sample selection method uses the Slovin formula in which the calculation of the formula obtained a minimum number of samples in West Nusa
Tenggara. The population of the vocational schools is 2,440 , so a minimum number of 344 students is obtained, therefore with respondents were high school students in 10 schools that live in disaster areas in Lombok, with a total of 779 high school students that is the number of respondents is sufficient to calculate the standard Slovin.

\section{Instrument}

To measure student resilience profiles were explored according to (Reivich \& Shatte, 2003) which included seven abilities as shown in Table 2 .

Table 2. Measuring Student Resilience Profiles were Explored according to Reivich \& Shatte (2003)

\begin{tabular}{llc}
\hline Aspect & Description & Item \\
\hline Emotional regulation & The ability to stay calm under stressful conditions. & 8 \\
Impulse control & $\begin{array}{l}\text { Individuals with strong impulse control tend to have high emotional regulation, } \\
\text { whereas individuals with low emotional control tend to accept impulsive beliefs. }\end{array}$ & 8 \\
Optimism & $\begin{array}{l}\text { Resilient individuals are optimistic individual, have hopes for the future, can } \\
\text { control the direction of their lives, physically fit, less likely to experience }\end{array}$ & 8 \\
& depression, perform better in school, more productive at work and excel in sports. \\
Causal analysis & The ability of individuals to accurately identify the causes of their problems. & 8 \\
Empathy & How well someone can understand other people related to the psychological, and & 8 \\
Self-efficacy & emotional conditions of that person. & 8 \\
& A person's confidence in the ability to solve problems experienced, and in & \\
Reaching out & achieving success. & 8 \\
\hline
\end{tabular}


To understand the role of the teacher in the development of students' resilience conducted with a qualitative approach by interviewing and conducting FGDs with teachers and students (show in Table 3).

Table 3. Categories of Personal Resilience Scores for High School Students in Lombok

\begin{tabular}{lc}
\hline Category & Score \\
\hline Very low & $x<41$ \\
Low & $41 \geq x<56$ \\
Quite low & $56 \geq x<71$ \\
High & $71 \geq x<86$ \\
Very high & $86 \geq x<100$ \\
\hline
\end{tabular}

\section{Analysis of Data}

Analysis of survey data about students' resilience profiles is used by calculating presentation, whereas to explore school strategies in building school resilience using qualitative data extracted by FGDs and interviews with 20 teachers from 10 schools. Qualitative data analysis begins with categorizing and interpreting data according to concepts relevant to aspects of personal resilience. Qualitative data validation was done by triangulating data from teachers and students. Observation and use of school data are used to strengthen qualitative data analysis.

\section{FINDINGS AND DISCUSSION Findings}

Based on the analysis of data on seven aspects of personal resilience: emotional regulation, impulse control, empathy, optimism, causal analysis, self-efficacy, and reaching out, can be detailed as follows.

\section{Emotional Regulation}

Emotional regulation is a term commonly used to describe a person's ability to effectively manage and respond to emotional experiences. Most of us use various emotional regulation strategies and can apply them to different situations to adapt to our environment. Dynamics regulation is the ability to stay calm under stressful conditions. Resilient individuals use skill installations that have been developed to help control their logs, attention, and behavior.

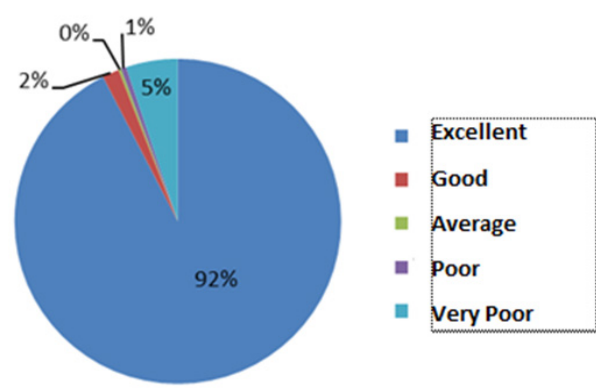

Figure 1. Personal Resilience of High School
Students in Terms of Emotional Regulation

Based on Figure 1, it is informed that high school students in Lombok have a very good emotional regulation aspect when dealing with problems in the school environment. A personal resilience of high school students in terms of the dominant emotional aspects in the very good category that is equal to $92.00 \%$. Seeing the range of high school students' assessments of emotional regulation aspects as expected (> 60.00\%) explains that high school students living in Lombok can control themselves to remain calm in dealing with problems that occur in the school environment and can also control emotions when facing disasters. Emotional regulation is the ability to stay calm inside stressful conditions. Resilient individuals use a series of skills that have been developed to help control emotions, attention, and behavior. Regulatory ability is important to establish interpersonal relationships, work success, and maintaining health physically.

\section{Impulse Control}

Impulse control is closely related to the ability of emotional regulation. Individuals with strong impulse control tend to have high emotional regulation, whereas individuals with low emotional control tend to accept impulsive beliefs, which consider a situation as truth and act on that basis.

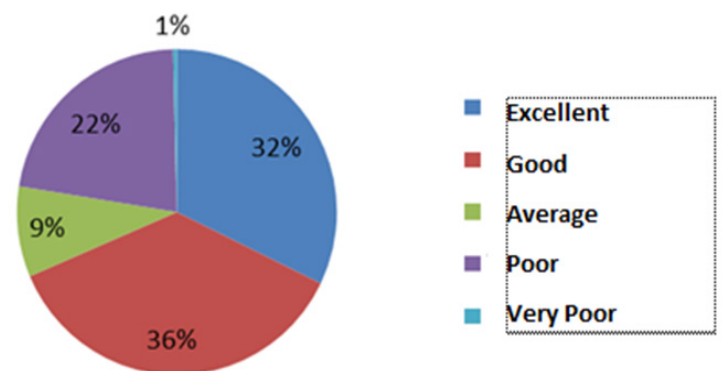

Figure 2. Personal Resilience of High School Students in Terms of Impulse Control 
Based on Figure 2, it was informed that the personal resilience of high school students living in Lombok from the aspect of impulse control was dominant in the good category. About $36.00 \%$ of high school students have the ability to control desires very well. Seeing the result did not reach expectations ( $>60.00 \%$ ), means that high school students have not been able to control their desire to act while facing a disaster. This reality illustrates that strengthening the impulse of control is still needed by students. To be able to develop impulse control can be trained on students, as the results of research.

\section{Empathy}

Empathy describes how well a person can read understand others relating to the psychological and emotional condition of that person. Some individuals can interpret other people's nonverbal behaviors, such as facial expressions, tone of voice and body language and determine what that person thinks and worries about. Inability in this case will have an impact on success and show non-resilient behavior.
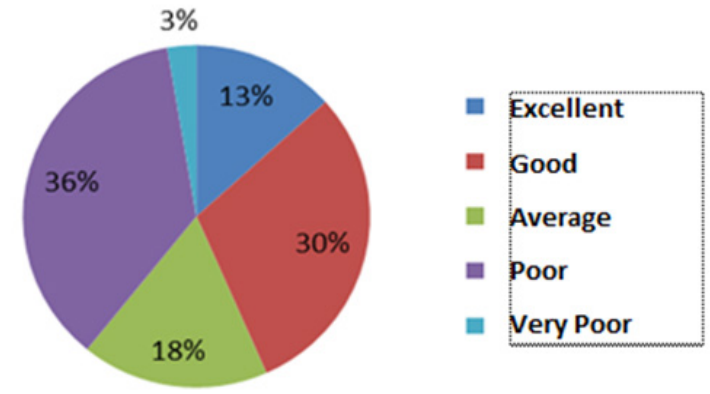

\section{Figure 3. Personal Resilience of High School} Students in Terms of Empathy

Based on Figure 3, it is informed that high school students have empathy aspects in the medium category which is equal to $37.00 \%$. The empathy attitude that students have has not reached expectations $(>60.00 \%)$. It means that high school students are less sensitive in reading psychological and emotional signs when a disaster occurs. Based on these results it can be concluded that schools still need to build students in forming empathic attitudes which are not easy to do, because the process of empathic formation has many domains.

\section{Optimism}

Resilient individuals are optimistic individuals. They believe that things can change for the better. Compared to pessimists, optimistic individuals are more physically fit, tend not to be depressed, perform better in school, more productive at work and excel in sports.

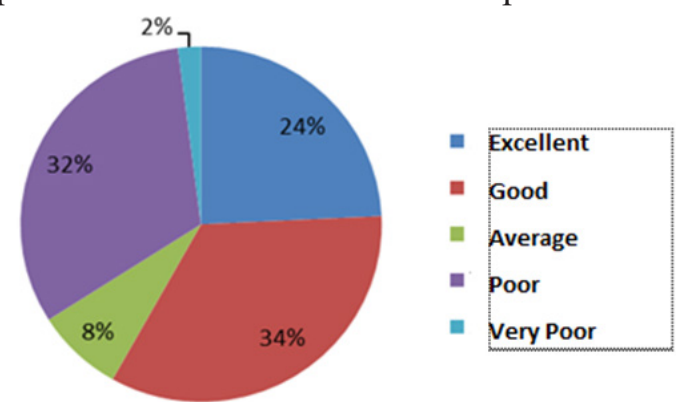

Figure 4. Personal Resilience of High School Students in Terms of Optimism

Seeing the results of the assessment based on Figure 4 that did not reach expectations ( $>$ $60.00 \%$ ) showed that high school students were pessimistic when facing a disaster directly. The above data proves that majority of the students have not been helped by a strong spirit of optimism, even though this aspect is an important element in dealing with problems.

\section{Causal Analysis}

Causal analysis is a term used to refer to the ability of individuals to accurately identify the causes of their problems. If someone is unable to accurately predict the cause of the problem, the individual will make the same mistake.
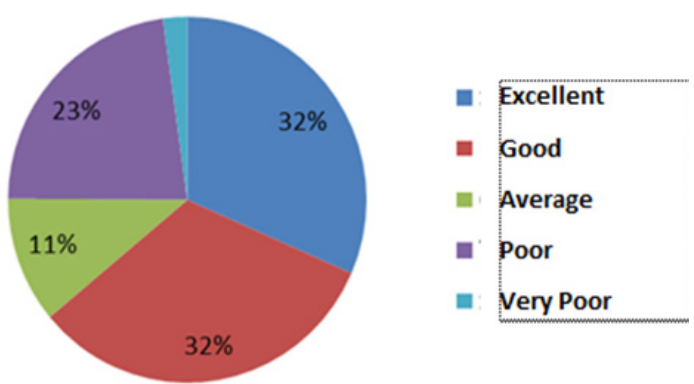

Figure 5. Personal Resilience of High School Students in Terms of Causal Analysis

Figure 5 informs that high school students in Lombok have the ability to analyze the causes of catastrophic events in the good category that is equal to $34.00 \%$. In terms of the ability of high school students to inform that high school students have not reached expectations $(>60.00 \%)$, meaning high school students in Lombok have not been able analyze the cause of the problem of a disaster and how to respond 
when a disaster event occurs. In fact, disasters that occur in unpredictable situations really require the right actions and decisions. With good analytical knowledge, students will have the knowledge needed that is the ability to do the right analysis of difficult situations by making the right and correct decisions.

\section{Self-efficacy}

Self-efficacy describes a person's belief in solving a problem and one's belief in his ability to achieve success. In the work environment, someone who has confidence in himself to solve problems appears as a leader.

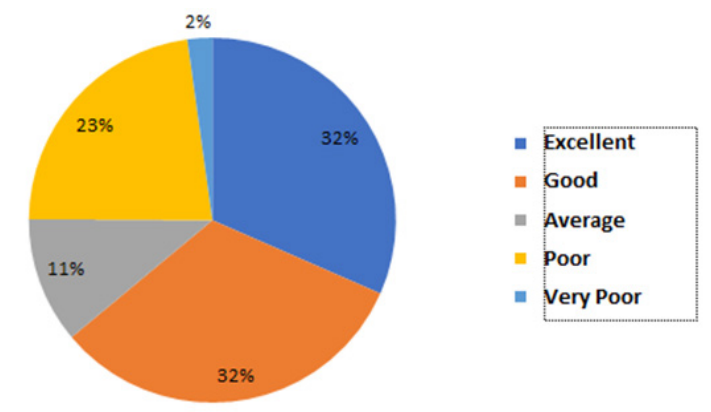

Figure 6. Personal Resilience of High School Students in Terms of Self-efficacy

Based on Figure 6, it was informed that the majority of high school students in Lombok could solve problems in the good category at $32.00 \%$. However, in general, the ability of high school students who did not meet the requirements $(>60.00 \%)$.

\section{Reaching Out}

Reaching out describes a person's ability to achieve success. Resilience is a source of reaching out because resilience enables us to improve the positive aspects of life.

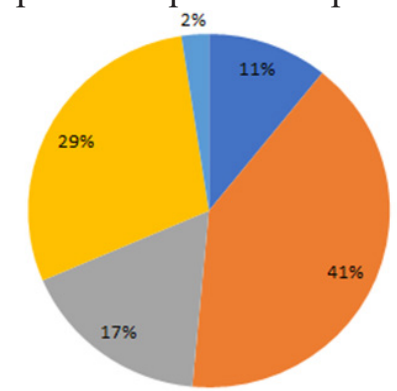

- Excellent

- Good

Inerage

II Poor

- Very Poor

Figure 7. Personal Resilience of High School Students in Terms of Reaching Out

Based on Figure 7, it is informed that in terms of the aspects of reaching out, high school students in Lombok can achieve positive aspects of disaster events experienced in the good category that is equal to $41.00 \%$. Seeing the results that have not reached expectations $(>60.00 \%$ ) explains that students have not been able to distinguish between realistic and unrealistic risks. Based on the description above, it can be informed that students are indicated to have poor awareness of personal resilience that characterized by students not being able to control themselves well (controlling emotional regulation, impulse control, empathy, optimism, self-efficacy, and reaching out). Resilience High school students in Lombok are still not in line with actual expectations (> 60.00\%).

The results of this study prove that most students do not have the "skills" that are needed in disaster mitigation. The ability to overcome the effects of disasters must be developed personally or in groups. This is important because the problems faced are individual and community. Teachers should start teaching and practicing some of the "skills" needed for disaster mitigation, such as cognitive problem solving, social skills, process skills, system skills.

From the analysis in Figure 8 based on the score categories in Table 2, it can be concluded that students' resilience falls into the quite low category. This explains that the personal resilience of high school students in Lombok needs improvement.

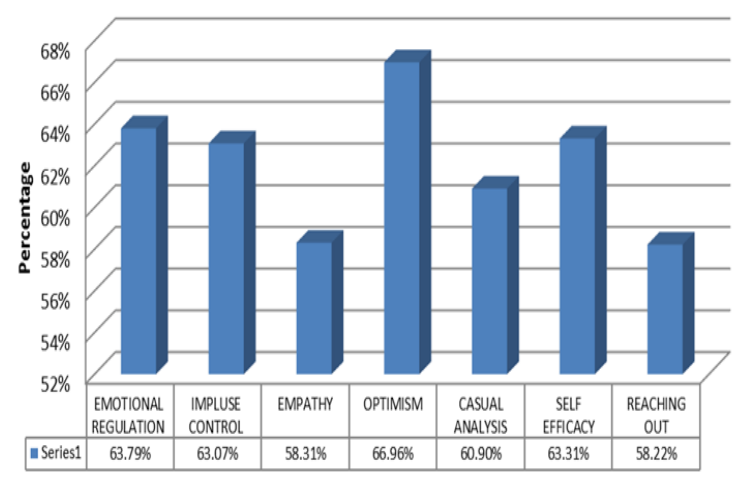

Figure 8. Recapitulation of Student Personal Resilience Profiles of High School Students in Lombok 2018

Based on Figure 8 data exposure, it can be concluded that resilience should be understood comprehensively. Resilience is not just a psychological concept but has a contribution to personal development which is related to 
the relational dimensions and organizational settings. Resilience is related to social dynamics experienced by individuals in responding to various problems by making positive adaptations, so as to be able to be calm in the face of disaster events. Schools need to build resilience, especially in the learning process at school. Students begin to be taught the value of harmony with disasters and are ready for disaster events. Students must be prepared to face disasters while remaining calm.

To understand the role of the teacher in the development of students' resilience, FGD and product test was limited to students and teachers, and the information in the Table 4 was obtained.
Based on Table 4, it can be concluded that many strategies can be chosen to develop resilience. Various studies emphasize that resilience can be fostered through various techniques, for example, the use of humor, relaxation techniques, and positive ways of thinking. Therefore, resilience is not seen as a fixed trait because it can be taught or improved. Reivich \& Shatte (2003) through research on skills training to increase resilience have found that individuals involved in the training feel stronger, confident, feel comfortable to connect with others, eager to find new experiences, and more willing to take risks.

Table 4. The Development of Student Personal Resilience

\begin{tabular}{|c|c|}
\hline Aspect & How to Strenghten \\
\hline $\begin{array}{l}\text { Emotional } \\
\text { regulation }\end{array}$ & $\begin{array}{l}\text { a. Develop skills by controlling emotions, attention, and behavior; } \\
\text { b. Develop the ability to establish interpersonal relationships; } \\
\text { c. Maintain physical health in achieving success at work. }\end{array}$ \\
\hline Impulse control & $\begin{array}{l}\text { a. Develop skills with strong impulse control; } \\
\text { b. Develop the ability of social adaptation to be calm in every situation; } \\
\text { c. Manage behavior wisely and not emotionally. }\end{array}$ \\
\hline Optimism & $\begin{array}{l}\text { a. Develop an attitude of optimism; } \\
\text { b. Develop beliefs about a better future with confidence; } \\
\text { c. Maintain the spirit of achievement, productive in work. }\end{array}$ \\
\hline Causal analysis & $\begin{array}{l}\text { a. Don't make mistakes due to the same cause; } \\
\text { b. Learn to overcome various problems wisely; } \\
\text { c. Learn to analyze the source of problems precisely and objectively. }\end{array}$ \\
\hline Empathy & $\begin{array}{l}\text { a. Learn to understand other people's behavior from verbal and nonverbal } \\
\text { expressions; } \\
\text { b. Learn to understand the thoughts of others; } \\
\text { c. Learn to understand others through empathic communication and being } \\
\text { patient. }\end{array}$ \\
\hline Self-efficacy & $\begin{array}{l}\text { a. Have confidence that every problem can be overcome; } \\
\text { b. Have the ability to succeed in achieving goals; } \\
\text { c. Have a clear target in achieving life goals. }\end{array}$ \\
\hline Reaching out & $\begin{array}{l}\text { a. Develop the ability to succeed in achieving the desired goals; } \\
\text { b. Develop positive aspects of life; } \\
\text { c. Have the ability to predict goals and results. }\end{array}$ \\
\hline
\end{tabular}

\section{Discussion}

Resilience is a complex interactive process because it involves various characteristics, individuals, families, and the community (Meichenbaum \& Melissa, 2008). Resilience as a concept is more widely used in ecology and has not been an important study in other fields such as stressing the importance of social systems and biophysical systems to deal with various hazards of disaster and how people can recover after disasters (Shiwaku et al., 2016). Resilience is one's capacity to able to function and competent in dealing with stressors and addressing various situations in the environment that pose risks (van Breda, 2001). Kalil (2003) argues that resilience is more the result of efforts to manage various kinds of things that have the potential to cause a crisis in positive ways 
(Duncan, Bowden \& Smith, 2005). Therefore, the concept of resilience by using examples of resilient children as children who do better than they should, and keeping in mind what has happened to them (Gilligan, 2001). Resilience is described as competence in dealing with difficulties (Hamill, 2003), as "a set of qualities that helps one to withstand the many negative effects of difficulties and defines resilience as the potential to show resources by using internal and external resources in responding to various contextual and evolving challenges. (Pooley \& Cohen, 2010), and refer to resilience as the process, capacity for, or outcome of successful adaptation despite challenging circumstances. (Abiola \& Udofia, 2011). Resilience as meaning inner strength, competence, optimism, flexibility, and the ability to deal effectively when faced with difficulties, by minimizing the impact of risk factors, such as stressful life events, and increasing protective factors, such as optimism, social support, and active coping, which enhance people's ability to face life's challenges and disasters. Therefore, the study of resilience about which was initially studied by physicists, engineers, and ecologists, later became a study by social scientists began to be interested in the importance of building the concept of resilience for various studies, and analysis of regional economics and the importance of forming independence and environmental support systems, more specifically the school environment has a very strategic role in building resilience (Parker, 2020).

The results of research on the personal resilience profile for students in Lombok have not described the ideal profile, because the average score is from seven: aspects emotional regulation, impulse control, empathy, optimism, causal analysis, self-efficacy, and reaching out; because based on the calculation the average result is not above $60 \%$. Based on these main findings, this section will discuss several important aspects that must be done by schools to increase the resilience of students living in disaster-prone areas to increase personal resilience more optimally.

\section{Increasing the Source of Student Resilience}

The first strategy that must be done to increase student resilience is by understanding the sources of resilience that students have and efforts to increase it. The source of resilience is broadly distinguished by two factors namely risk factors and protective factors (Karina, 2014; Dewi \& Hendriani, 2014) which both need to be synergized. More specifically Grotberg (1999) explains the various aspects related to the formation of resilience. It is stated that risk factors from resilience can come from a variety of sources, both external (family), or internal (self), while protective factors originating from the process of positive adjustment where these factors lead to improvement or protection against risk factors when facing adversity or misfortune (Nasution, 2011). Protective factors have an important role in modifying the negative effects of the environment that are detrimental to life and can strengthen one's resilience. Chen \& George (2005) and Dewi \& Hendriani (2014) that can increase children's resilience and positive transition in adaptation and can reduce maladaptive and negative behavior. In this context, social capital becomes an important aspect in shaping resilience (Dwiningrum et al., 2013). By understanding the source of the student's resilience, schools can design various activities aimed at developing student resilience, both with personal and group approaches. The individual approach starts with understanding the problems faced by students by applying solutions to each different case, while the group approach emphasizes learning processes for developing resilience with effective and communicative collaborative activities that integrated into the various lesson.

\section{Strengthening of Social Support}

The second strategy is needed by students to increase their resilience by getting social support from family, school and society. (Pooley \& Cohen, 2010). The synergy of the elements forming resilience is determined by many factors namely personal factors, family cohesion and social resources that exist in Society. Schools are one of the strategic environments that shape school resilience. School resilience is formed by the strength of resilience that is owned by all individuals in the school, such as: principals, teachers, teaching staff, and students (Dwiningrum et al., 2013). With resilience capital, then someone will have the desire to overcome various problems in life or the ability of social adaptation in responding to various 
problems of life (Masten \& Shaffer, 2006; Hutter \& Kuhlicke, 2013). With resilience, a person will have a state of good mental health, functional abilities and social competence (Olsson, Bond, Burns, Vella-Brodrick \& Sawyer, 2003), More specifically, (Connor \& Davidson, 2003) explained that with resilience, a person will: be able to adjust to change, build a close and trusting relationship, see the positive side of every circumstance or condition, struggle for the best regardless of what happens, work towards the goal, take pride in achievement, know when and where to ask for help, focus and think clearly under pressure, consider yourself with a strong personality. Students who live in disaster-prone areas are urgently needed. With social support, it is hoped that students can develop stronger resilience. Social support will be more effective if it is built by social cohesion at the family, school, and community levels. Because social cohesion has a positive correlation with the formation of resilience, even though the relationship has varying strengths, it is determined by various factors such as the disaster recovery phase, community and information, as well as the support available in the event of a disaster, as well as the programs owned by the community. (Townshend, Awosoga, Kulig, \& Fan, 2014).

\section{Having Qualified and Resilient Teachers}

The third strategy is to increase student resilience if the school has teachers who have resilient personalities. The role of teachers not only helps with disaster mitigation but also has a role in improving the quality of education. Good teaching is filled with positive emotions. They are emotional and passionate creatures and connect with students so they must be filled with fun, creativity, challenges, and joy. In the aspect of resilience, human beings are born on the basis of biological life experiences and are developed through social competence, problemsolving skills, critical awareness, autonomy, and a sense of belonging, caring and caring education, positive expectations, positive learning environments, strong positive social communities, and supportive peer relationships (Day \& Gu, 2013). Students will be more enthusiastic to learn because the learning process will be developed the intellectual energy needed for more resilient students that resilience requires basic knowledge, that requires a clear design of interventions for mitigation purposes taking into account cultural aspects and situational content. A sociocultural approach is needed to intervene in building student resilience. Intervention programs to build resilience need protective resources and reduce children's risk exposure by reducing potential negative outcomes.

The results of the study are also supported by several expert opinions which state that there are many ways to develop resilience. As Arian (2005) notes, perspectives on resilience are highly diverse and the concept of resilience is highly elusive. To illustrate the concept, Gilligan (2001) uses the example of a resilient child as a child who does better than they ought to, bearing in mind what has happened to them. Arian (2005) goes on to discuss resilience as inferring hardiness, toughness, and resistance, along with somewhat paradoxically elasticity and flexibility. This suggests that resilience is both multi-faceted and multileveled and the range of available definitions reflects this in both their depth and their breadth. Resilience is described by Hamill (2003) as competence in the face of adversity and by Gilligan (2001) as "a set of qualities that help a person to withstand many of the negative effects of adversity." Pooley \& Cohen (2010) define resilience as "the potential to exhibit resourcefulness by using internal and external resources in response to different contextual and developmental challenge (Garmezy, 1991), refer to resilience as "the process of, capacity for, or outcome of successful adaptation despite challenging circumstances."

\section{Building Resilient School}

The fourth strategy is to build school resilience. Resilient students are determined by the school environment. Resilience in schools can be built with eight strategies (Day \& Gu, 2013), to teach, and to teach well over time "everyday resilience"; Resilience is closely associated with teachers' sense of identity and commitment; There is a close association between resilience and a strong sense of moral purpose; Teacher resilience-building is relational; School leadership matters; The capacity to be resilient is an important quality of successful school leaders; Resilience in teachers is essential, but it is not the only condition for them to be effective, and Building and sustaining the capacity for resilience is more than individual responsibility. 
Resilient teachers find it easier to do highquality work. Resilient teachers are not difficult to implement education in the 21 st century.

How to become a resilient, and highquality teacher can be learned from Finland, a country that is successful in the education process that applies the principles of quality and equality together. Also, to build resilience students need to develop three important aspects synergistically, namely, individual, family, and community (Grotberg, 1995). The first factor is individually related to various aspects as explained by Herman, Stewart, Diaz-Granados, Berger, Jackson, \& Yuen (2011), personality characteristics, self-efficacy, self-esteem, internal locus of control, optimism, intellectual capacity, positive self-concept, demographic factors (age, sex, ethnicity), hope, toughness, emotional regulation, and so on. The second factor, the closet environmental factor, is related to how the family's ability to build healthy relationships between family members; safety schools; social support from peers, and so on. The third factor is the community system related to how the condition of the school environment, community service, cultural factors, spirituality, and religion, as well as lack of experience related to violence, are related to the level of resilience.

Based on the results of this study further research is needed on the relationship between families, schools, and communities in building student resilience as capital to build school resilience. According to Everall, Altrows, \& Paulson (2006), models of resilience have predominantly focused on one of three operational definitions: resilience as a stable personality trait which protects individuals from the negative effects of risk and adversity; resilience as a positive outcome, which is defined by the presence of positive mental health such as positive self-concept and self-esteem, academic achievement, success at age-appropriate developmental tasks, etc.) and the absence of psychopathology, despite exposure to risk; and resilience as a dynamic process contingent upon interactions between individual and contextual variables that evolve (Metzl \& Morrell, 2014).

The development of resilience will support a person's ability to carry out his main tasks. In the relevant literature, protective factors are described as optimism, empathy, and self-esteem, direction or mission, firmness, and determination (Ungar, 2004). A protective factor is a positive factor in an individual's life, as well as a factor that predicts positive outcomes for the family and community that are related to one's success in life. In this case, resilience is described as a process in which a person uses protective factors to adjust to the risk factors involved in various life conditions or events (negative conditions) experienced during the process of individual development. Resilience also requires the synergy of three elements, as personal inclination, family cohesion, Social resources outside the family (Werner, 1989; Garmezy, 1991). Sources of personal disposition include structural flexibility, social skills or initiatives that demonstrate intelligence, communicative skills, and personal characteristics; sources of family cohesion include supportive family traits that require certain behavioral characteristics, such as warmth, courage, and assistance; and social resources outside the family including socioeconomic status, school experience and supporting communities (Olsson et al., 2003).

Furthermore, a study conducted by (Huang \& Lin, 2013) assesses student resilience as a personal trait, which involves the ability of individuals to face difficulties determined by four factors namely: empathy and interaction between people, cognitive maturity, problem solving and hope and optimism. Based on some of these definitions it can be concluded that resilience is a dynamic process because many factors influence the process of forming personal resilience. (Xiaorong, Zonghua, Xiuying, \& Alice, 2020). Therefore, understanding personal resilience, especially for students, is very important so that school can increase the level of student resilience.

\section{CONCLUSION}

The resilience of students should be understood by the teacher. Teacher efforts to build and develop personal resilience because they are needed to build more effective school resilience. Resilience has the readiness to play a role in disaster mitigation. Disaster mitigation requires social synergy between the roles of principals, teachers, and students in order to build strong social cohesion. Strengthening students' personal resilience requires an effective and comprehensive strategy. Therefore, the teacher has an important role to choose an effective 
way so that students can strengthen personal resilience more optimally because students are optimal for their role in disaster mitigation. The results of the study as a preliminary study of the importance of forming resilience in students especially those living in disaster-prone areas. However, success in building student resilience is also determined by the role and synergy of the family, school, and community environment.

\section{ACKNOWLEDGEMENTS}

This research was supported by the Ministry of Research, Technology, and Higher Education of the Republic of Indonesia who has provided research development funds 2019 with contract number 73/Research/PP/UN34.21/2019 and the chairman Institute for Research and Community Services, Universitas Negeri Yogyakarta. We thank the journal Cakrawala Pendidikan for publishing our article.

\section{REFERENCES}

Abiola, T., \& Udofia, O. (2011). Psychometric assessment of the Wagnild and Young's resilience scale in Kano, Nigeria. BMC Research Notes, 4(1), 509. https://doi. org/10.1186/1756-0500-4-509.

Arian, A. (2005). The concept of social resilience. In N. Friedland, A. Arian, A. Kirschenbaum, K. Amit, \& N. Fleischer (Eds.). The concept of social resilience. Haifa: The Technion. Samuel Neaman Institute, pp. 7-10.

Barankin, T., \& Khanlou, N. (2009). Growing up resilience. North America: Camh Publication.

Chen, J. D., \& George, R. A. (2005). Cultivating resilience in children from divorced families. The Family Journal, 13(4), 452-455. https://doi. org/10.1177/1066480705278686.

Connor, K. M., \& Davidson, J. R. (2003). Development of a new resilience scale: The Connor-Davidson Resilience Scale (CD-RISC). Depression and Anxiety, 18(2), 76-82. https://doi.org/10.1002/ da.10113.

Day, C., \& Gu, Q. (2013). Resilient teachers, resilient schools: Building and sustaining quality in testing times. London: Routledge.

Dewi, N. R., \& Hendriani, W. (2014). Faktor protektif untuk mencapai resiliensi pada remaja setelah perceraian orangtua. [A protective factor for achieving resilience in adolescents after parental divorce]. Jurnal Psikologi Kepribadian dan Sosial, $3(1), \quad 37-43$. http://journal.unair.ac.id/ JPKS@jurnal-psikologi-kepribadian-dansosial-media-52.html.

Duncan, J., Bowden, C., \& Smith, A. B. (2005). Early childhood centres and family resilience. Wellington: Ministry of Social Development.

Dwiningrum, S. I. A., Prihastuti, P., \& Suwarjo. (2013). Social Capital and resilience school for disaster mitigation education in Yogyakarta schools. Jurnal Kependidikan, l(1), 84-99. https://doi.org/10.21831/ jk.v1i1.10091.

Everall, R. D., Altrows, K. J., \& Paulson, B. L. (2006). Creating a future: A Study of resilience in suicidal female adolescents. Journal of Counseling \& Development, 84(4), 461-470. https://doi. org/10.1002/j.1556-6678.2006.tb00430.x.

Garmezy, N. (1991). Resiliency and vulnerability to adverse developmental outcomes associated with poverty. American Behavioral Scientist, 34(4), 416-430. https://doi.org/10.1177/00027642910340 04003.

Gilligan, R. (2001). Promoting resilience: A resource guide on working with children in the care system. London: British Agencies for Adoption and Fostering.

Gowan, M. E., Kirk, R. C. \& Sloan, J. A. (2014). Building resiliency: A cross-sectional study examining relationships among health-related quality of life, well-being, and disaster preparedness. Health and Quality of Life Outcomes, 12(85), 1-17. https://doi.org/10.1186/1477-7525-12-85.

Grotberg, E. H. (1995). A guide to promoting 
resilience in children: Strengthening the human spirit - Early childhood development: Practice and reflection Number 8. The Hague: Bernard van Leer Foundation.

Grotberg, E. H. (1999). Tapping your inner strength: How to find the resilience to deal with anything. Oakland, CA: New Harbinger Publications.

Hamill, S. K. (2003). Resilience and selfefficacy: The importance of efficacy beliefs and coping mechanisms in resilient adolescents. Colgate University Journal of the Sciences, 35, 115-146. http:/groups. colgate.edu/cjs/student_papers/2003/ Hamill.pdf.

Herman, H., Stewart, D. E., Diaz-Granados, N., Berger,E. L., Jackson, B., \& Yuen, T.(2011). What is resilience? The Canadian Journal of Psychiatry, 56(5), 258-265. https://doi. org/10.1177/070674371105600504.

Huang, Y. C., \& Lin, S. H. (2013). Development of the inventory of college students' resilience and evaluating the measurement invariance. British Journal of Guidance \& Counselling, 41(5), 471-486. https://doi. org/10.1080/03069885.2012.749973.

Hutter, G., \& Kuhlicke, C. (2013). Resilience, talk and action: Exploring the meanings of resilience in the context of planning and institutions. Planning Practice and Research, 28(3), 294-306. https://doi.org /10.1080/02697459.2013.787706.

Kalil, A. (2003). Family resilience and good child outcomes: A review of literature. Wellington: Ministry of Social Development, Centre for Social Research and Evaluation.

Karina, C. (2014). Resiliensi remaja yang memiliki orang tua bercerai. [Resilience of adolescents with divorced parents]. Cognicia, 2(1). https://doi.org/10.22219/ COGNICIA.Vol2.No1.\%25p.

Masten, A. S., \& Shaffer, A. (2006). How families matter in child development: Reflections from research on risk and resilience. In A.
Clarke-Stewart \& J. Dunn (Eds). Families count. Cambridge: Cambridge University Press, pp. 5-25. https://doi.org/10.1017/ CBO9780511616259.002.

Meichenbaum, D., \& Melissa. (2008). Bolstering resilience: Benefiting from lesson learned. In D. Brom, R. Pat-Horenczyk, \& J. D. Ford (Eds.). Treating traumatized children: Risk, resilience and recovery. New York, NY: Routledge, pp. 183-192. https://doi.org/10.4324/9780203893104.

Metzl, E. S., \& Morrell, M. A. (2014). The role of creativity in models of resilience: Theoretical exploration and practical applications. Journal of Creativity in Mental Health, 3(3), 303-318. https://doi. org/10.1080/15401380802385228.

Nasution, S. M. (2011). Resiliensi daya pegas menghadapi trauma kehidupan. [Resilience of resilience in dealing with life trauma]. Medan: USU Press.

Olsson, C. A., Bond, L., Burns, J. M., VellaBrodrick, D., \& Sawyer, S. (2003). Adolescent resilience: A concept analysis. Journal of Adolescence, 26(1), 1-11. https://doi.org/10.1016/S01401971(02)00118-5.

Parker, D. J. (2020). Disaster resilience - a challenged science. Environmental Hazard, 19(1), 1-9. https://doi.org/10.108 0/17477891.2019.1694857.

Pooley, J. A., \& Cohen, L. (2010). Resilience: A definition in context. The Australian Community Psychologist, 22(1), 30-37. https://groups.psychology.org.au/Assets/ Files/Pooley.pdf.

Reivich, K., \& Shatté, A. (2003). The resilience factor: 7 keys to finding your inner strength and overcoming life's hurdles. New York, NY: Harmony.

Shiwaku, K., Sakurai, A., \& Shaw, R. (2016). Disaster resilience of education systems: Experiences from Japan. Tokyo: Springer.

Suhardjo, D. (2011). Arti penting pendidikan mitigasi bencana dalam mengurangu 
resiko bencana. [The Significance of Disaster Mitigation Education in Reducing Disaster Risks]. Cakrawala Pendidikan, 30(2), 174-188. https://doi.org/10.21831/ cp.v0i2.4226.

Tohani, E., \& Wibowo, L. (2019). The role of social capital in disaster management of disaster vulnerable village community. Cakarawala Pendidikan, 38(3), 527-539. https://doi.org/10.21831/cp.v38i2.21821.

Twigg, J., \& Bhatt, M. R. (eds) (1998) Understanding vulnerability: South Asian perspectives. London: Intermediate Technology Publications on behalf of Duryog Nivaran.

Ungar, M. (2004). The importance of parents and other caregivers to the resilience of highrisk adolescents. Family Process, 43(1), 23-41. https://doi.org/10.1111/j.15455300.2004.04301004.x.
Van Breda, A. D. (2001). Resilience theory: A literature review. Pretoria, South Africa: South African Military Health Service.

Werner, E. E. (1989). High-risk children in young adulthood: A longitudinal study from birth to 32 years. American Journal of Orthopsychiatry, 59(1), 72-81. https://doi. org/10.1111/j.1939-0025.1989.tb01636.x.

Weichselgartner, J., \& Pigeon, P. (2015). The role of knowledge in disaster risk reduction. International Journal of Disaster Risk Science, 6(2), 107-116. https://doi. org/10.1007/s13753-015-0052-7.

Xiaorong, M., Zonghua, W., Xiuying, H., \&Alice, Y.L. (2020). A scoping review of resilience scales of adults to develop a prototype disaster resilience tool for healthcare rescuers. Educational Resilience from Parental Perspective, 49. https://doi. org/10.1016/j.ijdrr.2020.101678. 